\title{
A FORMAÇÃO ESTÉTICA NO COMPARTILHAMENTO DE IMAGENS ENTRE OS ACADÊMICOS DO CURSO DE FOTOGRAFIA
}

\author{
THE AESTHETIC FORMATION IN THE SHARING OF IMAGES AMONG \\ THE ACADEMICS OF THE PHOTOGRAPHY COURSE

\section{LA FORMACIÓN ESTÉTICA EN EL COMPARTO DE IMÁGENES ENTRE ESTUDIANTES DE LA CARRERA DE FOTOGRAFÍA}

\author{
Elisabete Freitas Teixeira ${ }^{1}$ Luciana Backes ${ }^{2}$
}

\begin{abstract}
RESUMO
O presente artigo emerge a partir das reflexões sobre a formação estética, alicerçado em produções fotográficas e representações escritas construídas pelos acadêmicos de fotografia compartilhadas na mídia social "Facebook". Estes acadêmicos fazem parte de uma disciplina de fotografia ministrada pela autora e as atividades constituem este lócus investigativo. Assim, o problema se apresenta do seguinte modo: Quais são os sinais gerados pelos sujeitos participantes, por intermédio de compartilhamento nesta mídia social considerando a formação estética desses acadêmicos? Instigada nesta problemática, os dados empíricos observados nas interações no Facebook foram submetidos a metodologia de análise do conteúdo abordando a semiótica, ou seja, uma análise propondo uma dupla visão ao objeto, conectando imagem e escrita. A partir da proposta pedagógica evidenciamos nas análises um amplo crescimento nas
\end{abstract}

\footnotetext{
${ }^{1}$ Mestre em Educação e Doutoranda pela Umilasalle.Seu projeto de tese está articulado ao projeto de pesquisa "Educação On-Line: reconfigurações, reconstruções e significados na prática pedagógica para o ensino e aprendizagem", desenvolvido no Grupo de pesquisa Convivência e tecnologia digital na contemporaneidade - COTEDIC UNILASALLE/CNPq, pertencente a linha de pesquisa "Culturas, Linguagens e Tecnologias na Educação", do Programa de Pós-graduação em Educação da Universidade La Salle. Docente de curso Superior pela Ulbra (Fotografia e Publicidade e Propaganda).

${ }^{2}$ Possui graduação em Pedagogia Habilitação Magistério e Séries Iniciais pela Universidade do Vale do Rio dos Sinos (1996), especialização em Informática na Educação pela Universidade Federal do Rio Grande do Sul (2002), mestrado em Educação pela Universidade do Vale do Rio dos Sinos (2007) e doutorado em Educação pela Universidade do Vale do Rio dos Sinos (2011) e Sciences de l'Education pela Université Lumière Lyon 2 (2011). Bolsa de Estágio Pós-Doutoral no Exterior CAPES, na l'Université Paris Descartes Paris V - Sorbonne (2013-2014). Professora titular do Centro Universitário LaSalle - Unilasalle, Programa de Pós-Graduação em Educação. Tem experiência na área de Educação, com ênfase em Educação Digital, atuando principalmente nos seguintes temas: processos de ensino e de aprendizagem, construção do conhecimento, formação do educador, práticas pedagógicas, informática na educação, educação on-line, ambiente virtual de aprendizagem, metaverso, hibridismo tecnológico digital, Espaço de Convivência Digital Virtual - ECODI, comunidades virtuais de aprendizagem, processo de autonomia, processo de autoria, dimensões do acoplamento estrutural, cultura emergente. Líder do Grupo de Pesquisa Convivência e Tecnologia Digital na Contemporaneidade COTEDIC UNILASALLE/CNPq. Pesquisadora visitante ao Laboratoire Sciences, Société, Historicité, Education, Pratiques (S2HEP) Université Claude Bernard Lyon 1.
}

\begin{tabular}{l|l|l|l}
\hline Rev. Ciências Humanas & Frederico Westphalen, RS & Vol. 19 n. 01 & Jan./abr. 2018 \\
\hline
\end{tabular}

\begin{tabular}{l|l|l} 
Recebido em: 18/04/2018 & Aceito em: 01/06/2018 & Pg. 95 - 119
\end{tabular}




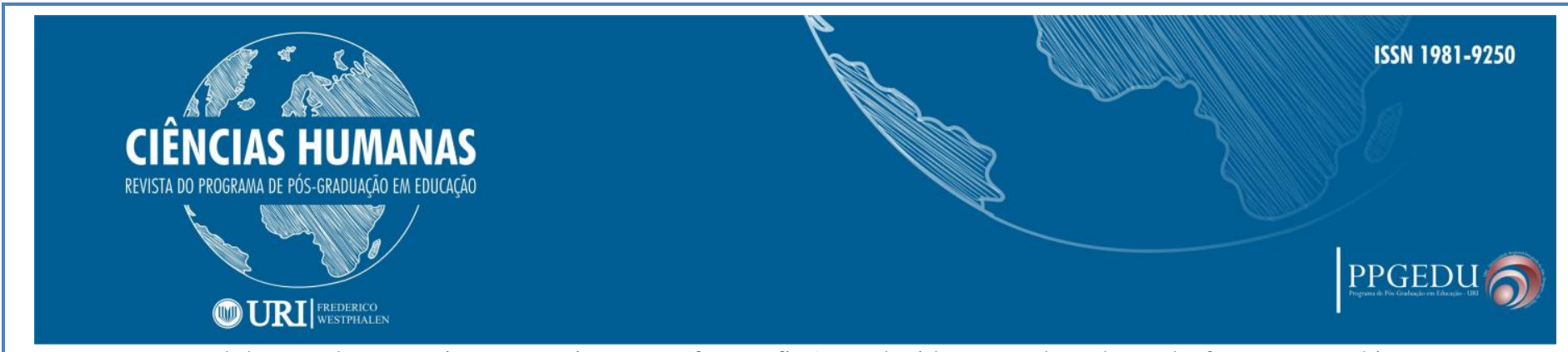

modulações das narrativas e nas imagens (fotografias) produzidas, corroboradas pela formação estética dos acadêmicos ao passo que sentiam-se tocados pelo contexto. Sentidos e sentimentos que aos poucos, contribuíram para o desenvolvimento dos acadêmicos de modo crítico, inspirador e transformador. A cada narrativa escrita e captura fotográfica percebe-se a formação estética em histórias singulares, composições, luzes, linguagens e ou ângulos inusitados.

PALAVRAS-CHAVE: Formação Estética. Imagens. Fotografia.

\begin{abstract}
The present article emerges from the reflections on the aesthetic formation, based on photographic productions and written representations constructed by photography students shared on the social media Facebook. These academics are part of a photography subject taught by the author and the activities constitute this investigative locus. Thus, the problem is presented as follows: What are the signs generated by the participants, through sharing in this social media considering the aesthetic formation of these academics? Instigated with this problematic, the empirical data observed in the interactions on Facebook were submitted to a contente analysis methodology approaching the semiotics, that is, an analysis proposing a double vision to the object, connecting image and writing. From the pedagogical proposal, we show in the analysis a great growth in the modulations of the narratives and in the images (photographs) produced, corroborated by the aesthetic formation of the students while they felt touched by the context. Senses and feelings that gradually contributed to the development of the academics in a critical, inspiring and transformative way. Each written narrative and photographic capture one perceives the aesthetic formation in singular histories, compositions, lights, languages and or unusual angles.
\end{abstract}

KEYWORDS: Aesthetic Formation. Images. Photography.

\title{
RESUMEN
}

El presente artículo emerge a partir de reflexiones sobre la formación estética, anclado en producciones fotográficas y representaciones escritas construidas por estudiantes de fotografía compartidas en "Facebook". Estos estudiantes hacen parte de una asignatura de fotografía impartida por la autora y las actividades constituyen este locus investigativo. El problema se presenta del siguiente modo: ¿Qué signos generan los participantes, por medio del comparto en esta media social, considerando la formación estética de esos estudiantes? Instigados en esta problemática, los datos empíricos observados en las interacciones en Facebook han sido sometidos a metodología de análisis de contenido abordando la semiótica, es decir, un análisis proponiendo doble vista al objeto, conectando imagen y escritura. Desde la propuesta pedagógica evidenciamos en los análisis amplio crecimiento en las modulaciones de las narrativas y en las imágenes (fotografías) producidas, corroboradas por la formación estética de los estudiantes, al paso que se sentían tocados por el contexto. Sentidos y sentimientos que, a los pocos, han contribuido al desarrollo de modo crítico, inspirador y transformador. A cada narrativa escrita y captura fotográfica, se percibe la formación estética en historias singulares, composiciones, luces, lenguajes y/o ángulos inusitados.

PALABRAS CLAVE: Formación Estética. Imágenes. Fotografía.

\section{INTRODUÇÃO}

O artigo especifica a formação estética discutida a partir do projeto de Tese intitulada Educação para o olhar e a formação estética: pistas a partir do uso da rede social pelos acadêmicos do curso de fotografia. $O$ projeto tem como temática

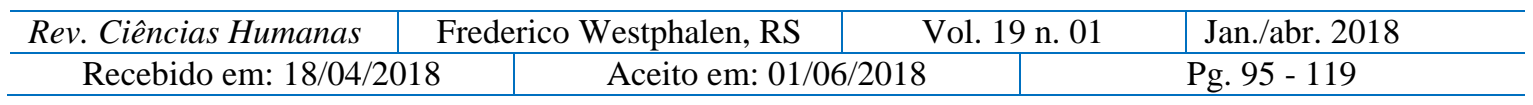




\section{CIÊNCIAS HUMANAS}

REVISTA DO PROGRAMA DE PÓS-GRADUAĞ̈O EM EDUCAĞ̄o

\section{(1) URI|}

investigativa sinais sobre a educação para o olhar e a formação estética daquele que olha, a partir de produções fotográficas e representações escritas construídas pelos acadêmicos de fotografia compartilhadas na mídia social "Facebook". Na especificidade, discute os possíveis sinais produzidos na articulação entre imagens (fotografias) e narrativas escritas pelos acadêmicos do curso de Fotografia, práticas que se desenvolveram como processo de ensino e de aprendizagem pela busca investigativa na formação estética destas experiências compartilhadas na mídia social. Esses acadêmicos são universitários participantes da disciplina de Eventos Sociais, ministrada pela pesquisadora, desenvolvida por meio da mídia social "Facebook", que contribui para os processos formativos desta atividade. A mídia social foi escolhida devido a sua interface de navegação, para a interação, compartilhamento, socialização e $\operatorname{trocas}^{3}$ de saberes. A participação efetiva desse coletivo nos permite analisar os possíveis sinais na formação estética de suas imagens e a relevância atribuída a elas através de suas narrativas, que por consequência ampliam os compartilhamentos e o convívio em rede. Aprendizagens que fomentadas pela formação estética potencializam a (re)construção destes acadêmicos enquanto sujeitos/atores/narradores/coatores.

O projeto de tese está articulado ao projeto de pesquisa "Educação On-Line: reconfigurações, reconstruções e significados na prática pedagógica para o ensino e aprendizagem", desenvolvido no Grupo de pesquisa Convivência e tecnologia digital na contemporaneidade - COTEDIC UNILASALLE/CNPq, pertencente a linha de pesquisa “Culturas, Linguagens e Tecnologias na Educação", do Programa de Pós-graduação em Educação da Universidade La Salle.

$\mathrm{O}$ artigo inicialmente apresenta "o método de análise de dados" comtemplando o processo de investigação da pesquisa, após é desenvolvida a temática "a Formação Estética Contemporânea", conduzida a partir de observações quanto às transições e transformações por efeito da prática pedagógica, processo de aprendizagem, construção do conhecimento, compartilhamentos e interação entre os sujeitos. Isto é, através do processo de construção - imagens e narrativa escrita - e interação, estes acadêmicos são sensibilizados e se constituem em um processo evolutivo que emerge variadas formas

\footnotetext{
${ }^{3}$ As trocas podem ser em qualquer sentido: sentimento, afeto, amizade, emoção, paixão, conhecimento.
} 


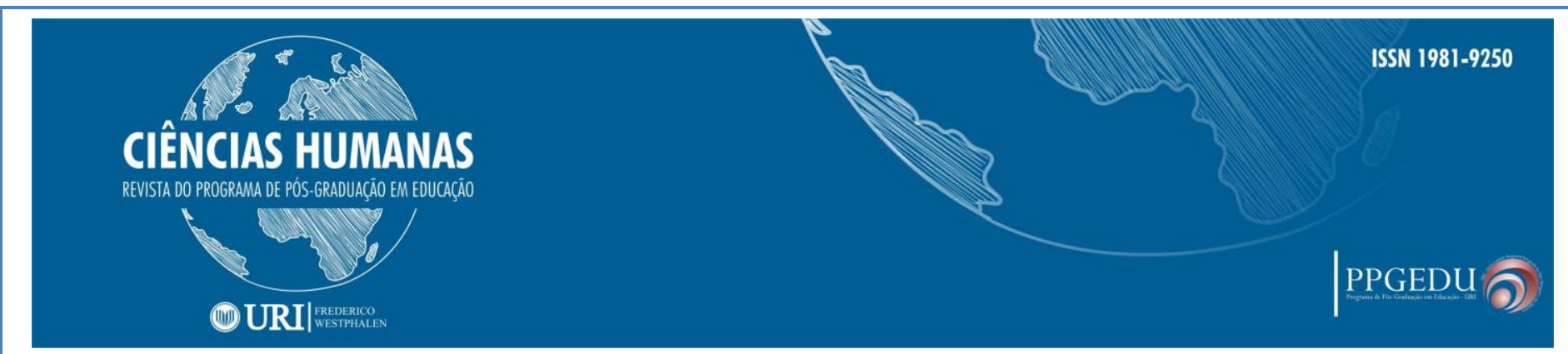

de perceber, compor, sentir e ser tocado. A seguir, a pesquisadora realiza a análise do conteúdo imagético e narrativas escritas pelos caminhos investigativos da semiótica, buscando conexão entre os mesmos com o referencial teórico abordado, contextualizado na temática que foi desenvolvida: a formação estética. Os possíveis sinais gerados por esta nova experiência, novo perceber, novo sentir, novo tocar e ser tocado por interferência da imagem produzida e compartilhada com os "outros" acadêmicos do grupo, ao passo que, essas trocas auferem um novo aprendizado, uma nova maneira de "estar junto" e uma nova formação estética.

\section{MÉTODO DE ANÁLISE DE DADOS}

No processo de investigação científica, não estamos mais a proferir apenas o outro, enquanto sujeito maior deste contexto educacional, mas o outro (sujeito) em articulação com o objeto, logo, traçar esse caminho, no campo da pesquisa em educação, indica a ampliação do objeto de análise. E foi então, na pretensão desta busca, que emergiu a prática pedagógica proferida e analisada.

Cada aluno (sujeito) da disciplina de Eventos Sociais - meu campo de investigação - escolheu um evento para construir uma imagem fotográfica, da semana acadêmica (evento realizado na universidade), podendo ser de um workshop ou de uma palestra. Essa imagem com tema (livre) foi solicitada através de algumas orientações, não podendo ser construída através de qualquer click, está captura precisava ser pensada, analisada e planejada antes da sua efetivação. Visto que, a construção imagética deveria ser relatada na descrição da postagem compartilhada no Facebook, ou seja, no relato deve constar o porquê da escolha - qual foi a motivação; qual a relevância da imagem para quem a produziu; qual o sentido, significado ou mensagem que está mensurando; porquê a composição escolhida; luz; enquadramento; linguagem; o olhar; o aprendizado; a experiência; a estética ...Enfim, a escrita se faz tão importante quanto a imagem em si, devendo haver conexão entre ambas, para melhor esclarecer ao leitor a sua produção artística. E a pesquisadora realizará a análise do conteúdo imagético e escrita pelos caminhos investigativos da semiótica - que propõe uma análise de dupla visão - contextualizados na temática que foi desenvolvida: a formação estética. 


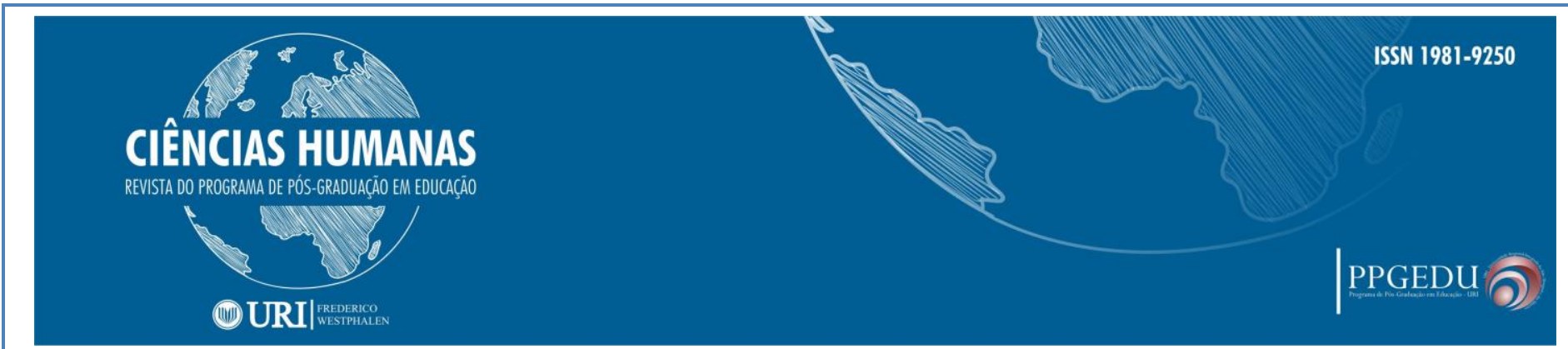

Atuando de forma crítica e criativa enquanto descreve, interpreta, explica, encadeia evidências e sinais gerados, logo, se propõe a oferecer uma visão holística do fenômeno estudado.

Análises que se projetam no tempo e no espaço e se constituem nas coisas como são, independente do que pensemos delas, de maneira bem mais acessíveis, tal o que se configura na proposta pragmatista.

\begin{abstract}
Em síntese: se, de um lado, os empiricistas tomaram o que está lá fora como um dado, os idealistas, de outro lado, deixaram de lado o fato de que há um ingrediente compulsivo em todo o julgamento de percepção, algo que nos acossa e que não depende do movimento da consciência. Como Peirce se posicionou diante dessas duas tendências opostas? A irredutibilidade da secundidade na percepção e na ação foi a chave peirceana para encontrar uma via média entre o racionalismo e o empiricismo, entre o idealismo e o realismo ingênuo. Ele juntou esses dois opostos num esquema triádico que não é nem realista, nem empiricista. É semiótico (SANTAELLA, 1998, 117).
\end{abstract}

Esta é uma investigação semiótica Peirciana, um método de análise que fornece um inventário de tipos de signos e misturas sígnicas, nas inumeráveis gradações entre o verbal e o não verbal até o limite do quase-signo. A partir dessa fonte conceitual, a autora revela poder extrair estratégias metodológicas para a leitura e análise de processos empíricos de signos. Com o objetivo de enfatizar o potencial significativo engendrado na imagem, por meio do exercício de um olhar capaz de contemplar, discriminar e generalizar os processos de interpretação, olhar esse que corresponde, respectivamente, aos três passos do processo interpretativo: da significação, da referência e da interpretação.

O primeiro olhar, contemplativo, corresponde à face da significação, é o momento em que nos detemos aos aspectos qualitativos vinculados às cores, às formas, às linhas, às texturas, ao movimento, às dimensões ou ao jogo de elementos. Aquilo que apela para a nossa sensibilidade são qualidades, estamos, portanto, numa instância do processo que exige sensorialidade.

O olhar que discrimina - observacional - diz respeito à referência, é a fase da objetivação. Nessa faceta, a análise semiótica nos permite compreender aquilo que as mensagens indicam, aquilo a que se referem ou a que se aplicam. Devem-se desenvolver considerações situacionais sobre o universo no qual o signo se manifesta e

\begin{tabular}{l|l|l} 
Recebido em: 18/04/2018 & Aceito em: 01/06/2018 & Pg. 95 - 119
\end{tabular}




\section{CIÊNCIAS HUMANAS}

REVISTA DO PROGRAMA DE PÓS-GRADUAĞ̈O EM EDUCAĞ̄o

\section{(10)URI|}

do qual é parte. Observando, ainda, aquilo que faz dele único em contextos socioculturais que estão fora dele, mas que o determinam. Por fim, o terceiro olhar, generalizante, leva-nos ao exame dos efeitos que os elementos apreendidos até então podem provocar no intérprete, entram aqui os conhecimentos do leitor sobre cada elemento da imagem que lê, conhecimento este que permitirá a articulação das qualidades atualizadas existentes no processo, que caracteriza a ação do signo produzindo outros signos.

Enfim, as análises constitutivas sobre a formação estética da prática pedagógicas dos acadêmicos estão alicerçadas sob o olhar semiótico, no qual, "a arte será reforçada enquanto objeto do conhecimento, ao passo que, transforma as suas condições de produção, circulação e socialização" (BENJAMIN, 1994, p. 168). Visto que, a construção desta pesquisa se constituiu fundamentada no título: “O que sua escrita diz sobre sua arte?"

\section{A FORMAÇÃO ESTÉTICA NO CONTEMPORÂNEO}

A contemporaneidade apresenta características que denotam novas formas de construção da realidade e maneiras ressignificadas de viver e conviver de uma era, características que estão sendo auferidas por uma nova estética ${ }^{4}$, também chamada por Maffesoli (2000) de estética transformadora. Para o autor esta estética "é como a faculdade comum de sentir, de experimentar" (p. 105). Nessa perspectiva, vive-se em um tempo, onde é notória a expansão relevante pelos acontecimentos - estar junto ${ }^{5}$ - e consequentemente da criatividade, desempenhando um papel primordial como ampliadores na modulação das narrativas daqueles que compartilham momentos de convivência. Aspectos corroborados pelo fomento do progresso tecnológico e

\footnotetext{
${ }^{4} \mathrm{O}$ termo "estética" foi empregado originalmente por Alexander Gottlieb Baumgarten (1714-1762) para dar título à sua obra Aesthetica, de 1750 (obra inacabada que tinha por objeto a análise e a formação do gosto); trata-se de um neologismo que provém do grego aisthesis cujos significado é sensação, sentimento.

${ }^{5}$ Relações que, segundo o autor, articulam e fundamentam a vida cotidiana e as maneiras de ser, pessoas que constituem-se na necessidade de pertencer ao ambiente ou espaço, de procurar um estilo, de partilhar emoções, sensações, valorizar a própria imagem e estabelecer laços sociais, "estar juntos".
} 


\section{CIÊNCIAS HUMANAS}

REVISTA DO PROGRAMA DE PÓS-GRADUAĞ̈O EM EDUCAĞ̄o

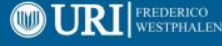

concomitante a ele a motivação exacerbada pela produção de imagens, propiciando aos sujeitos/atores pós-modernos novos modos de ver, perceber e apresentar o mundo por suas lentes. Perspectivas que corroboram significativamente na articulação de linguagens artísticas - fotografias e narrativas escritas - a um tipo de realidade multifacetada e híbrida, como veremos no decorrer desta pesquisa nas análises apresentadas.

No caminho investigativo que percorremos, os acadêmicos foram provocados a partir de uma metodologia teórica à produção e contribuição de suas imagens exibidas como sua arte em um novo compartilhar, interações de trocas que para Benjamin (1985), fazem parte da nova socialidade no contemporâneo. Acontecimentos que fomentam o surgimento de uma arte enraizada na práxis, que acaba direcionando os sujeitos/atores para uma vida cotidiana mais imediatista, vinculada ao "aqui" e "agora". Movimentos que surgiram pelo rompimento da estrutura grupal $^{6}$ potencializando a lógica das experiências, das emoções e dos sentimentos compartilhados (MAFFESOLI, 1996). Prática social interativa que promove confraternizar e compartilhar experiências e conhecimento em um novo viver e conviver, à medida que, ainda produz símbolos, sentidos, significados, imagens, linguagens e representações em suas produções. Um novo sentir que nos coloca em fusão de "estado poético", ou seja, em estado de emoção, de afetividade, de excitação, de prazer, ao passo que somos motivados inclusive pelo sentimento enquanto coletivo estar junto - criar laços afetivos.

No estado poético, ocorre o auto-reconhecimento a partir do reconhecimento do outro, seja esse "outro" um indivíduo, um espaço, um objeto, uma ideia, etc. Movimentos que nutrem a construção de subjetividade pela emoção, linguagem, pensar, sentir e pelo desejo. Estes desejos englobam a preocupação por uma estética do sensível, aquela que toca e comove aquele que olha, vê, percebe e observa, incluindo a busca pela beleza corpórea. Uma beleza que se torna efetiva em um jogo de aparências,

\footnotetext{
${ }^{6}$ Maffesoli (1995) refere-se ao rompimento de estrutura grupal ao entendimento de novas formas de agrupamentos sociais, enquanto tradutora das mudanças ocorridas nas redes de relações grupais. Caracterizadas por uma sensibilidade coletiva que ganha corpo através da emergência do fenômeno da tecnológica.
} 


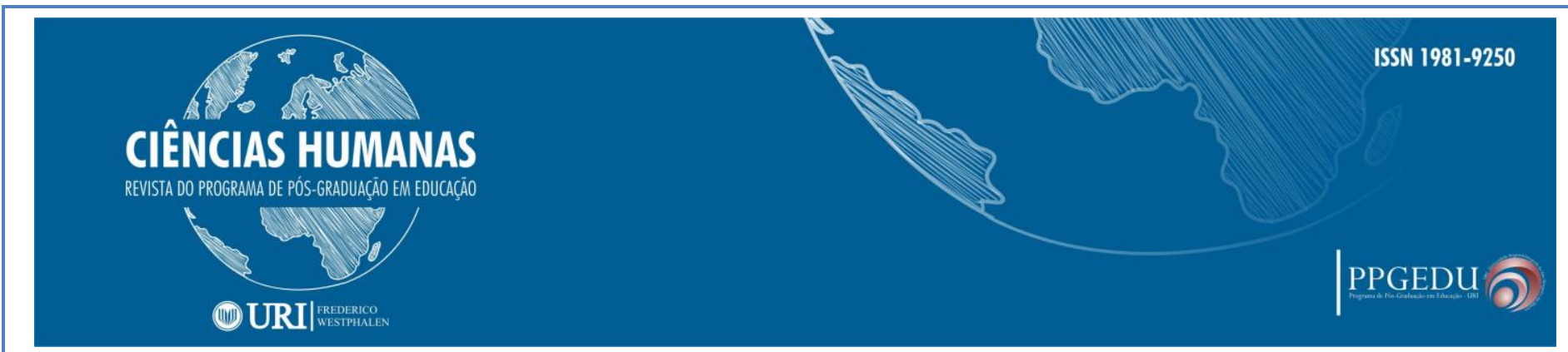

como reflexo de sintoma de cultura e com indícios que movimentam as práticas culturais de uma sociedade que busca a visualização. Estas são manifestações culturais com características efêmeras, híbridas e fragmentadas em uma cultura que pauta estilos de vida e visões de mundo, onde significados se atualizam nas constantes reconstruções. Manifestações que se dão também a partir da possibilidade de superação de fronteiras entre pensar, sentir e agir, em uma dimensão de entrelaçamento de culturas e formas de apreensão do mundo (MAFFESOLI, 1995).

Trata-se de uma sociedade tecnocultural midiatizada e conectada pela imagem, mitos, sentimentos, nostalgia e velocidade. Assim, construímos diversas interferências no entorno da formação estética por intermédio daquele que participa enquanto sujeito/ator/narrador- enquanto atua - ou coator - ou enquanto observa, participa e aprende com o outro. São interseções que podem ocorrer, por intermédio da crítica daquele que produz ou que vê a produção do "outro", pela inspiração que almeja encontrar em si ou pelo olhar do "outro" e ou pela transformação na percepção, no sentir, na sensibilidade do seu "eu".

Produzir imagens objetivando contribuir para o desenvolvimento formativo dos sujeitos/atores de modo crítico, inspirador e transformador amplia as fronteiras do saber, no entanto, para Benjamim (1994), a pós-modernidade tem percorrido sob a excessiva valorização da própria reprodução e sua produção exagerada potencializa a possibilidade de modos de experimentação e expressão, ou seja, são deslocamentos que reverberam para o esvaziamento da tradição e ou culto, enquanto valoriza-se a exibição da imagem. No entanto, o fato novo que aqui emerge, além da troca e ou socialidade, é viver-se numa era pulverizada não somente por modelos e categorias estéticas antigas do belo enquanto "eu" ou o "outro" no melhor da sua aparência, mas a estética que integra a imagem - fotografia - como "obra" na esfera industrial dessa cultura, chamada por Benjamin (1985) de "reprodutibilidade técnica".

A "reprodutibilidade técnica" possui relevância no contexto dessa pesquisa devido a inesgotável relação e aproximação da fotografia como arte. Nessa trilha, o sujeito/ator manifesta sua arte duplamente, tanto como ator quanto produtor. Uma produção que, para Benjamin (1985), tudo que se refere à arte, pode contemplar a perda da "aura" 


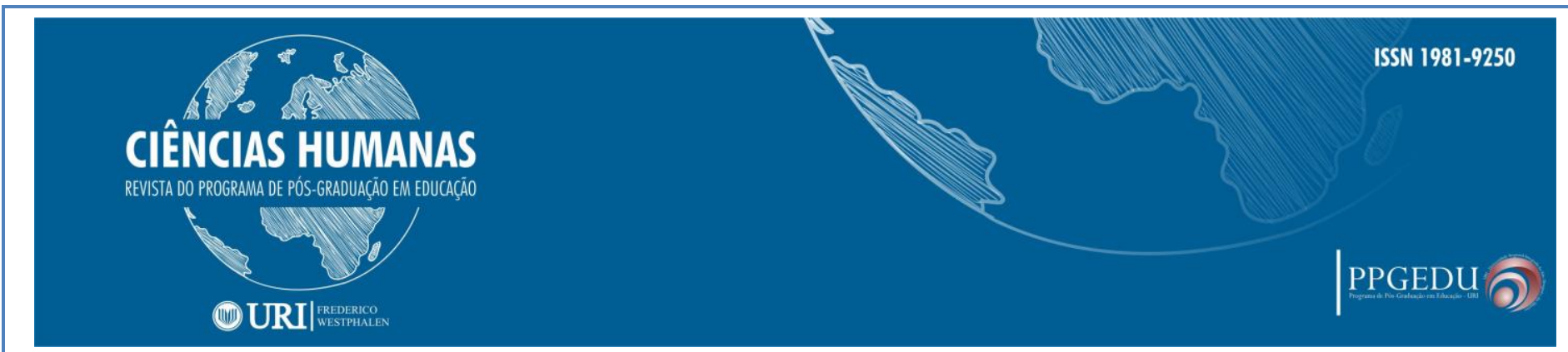

destas obras. Esse processo tem valor de sintoma, sua significação afirma Benjamin (1994) se expande para além do terreno da arte. A multiplicação de cópias, transformam o evento produzido em um fenômeno de massas, permitindo ao objeto reproduzido conferir-lhe atualidade permanente. Tal carência referente a perda da aura, ocorre devido à desvalorização do viver contemporâneo no "aqui e agora" que garante à obra original a sua autenticidade ${ }^{7}$ - o hic et nunc. Empiricamente, a obra de arte antiga apenas habitava o espaço específico em que estava (um aqui) e aquele tempo (um agora). A reprodutibilidade técnica por definição, trata a fotografia como cópia, ou seja, perde sua originalidade - o original são os negativos da obra. Rompia-se o testemunho histórico que a obra antiga concedia, uma vez que a sua autenticidade era a quintessência do que foi transmitido pela tradição; desaparece a autoridade da coisa original.

As questões levantadas por Benjamin (1985) em toda sua teoria estética, culminam em uma nova forma de pensar a arte, abrindo novas portas e inclusive janelas para o estudo da estética. Através de sua análise, a arte é reforçada enquanto objeto do conhecimento, quando transforma as suas condições de produção, circulação e socialização, ao passo, que busca a formação de forma crítica, inspiradora e transformadora.

Neste sentido, Benjamin (1994) contribui com seus conceitos a um futuro em constante construção, devido à capacidade de transformação desses sujeitos, estimulados pelos meios de comunicação, informação e mídias sociais que, por sua vez, colaboram para o desenvolvimento das interações cognitivas. Regados pela intensa corrente de informações e trocas, o autor referencia a elevação do potencial destes sujeitos na capacidade de adaptação em diferentes grupos e ou culturas, além da identificação de diferenças que são fatores relevantes para o aprendizado.

A partir destas decorrências, percorremos o caminho da estética sob uma função evolutiva, "estando seu significado pleno apenas num futuro distante sempre concretamente adiado. Um futuro idealmente pensável, mas materialmente inatingível"

\footnotetext{
${ }^{7}$ Para Benjamin (1994) o que caracteriza a autenticidade de uma obra é tudo aquilo que ela contém e é originalmente transmissível, desde sua duração material até seu poder de testemunho histórico.
} 


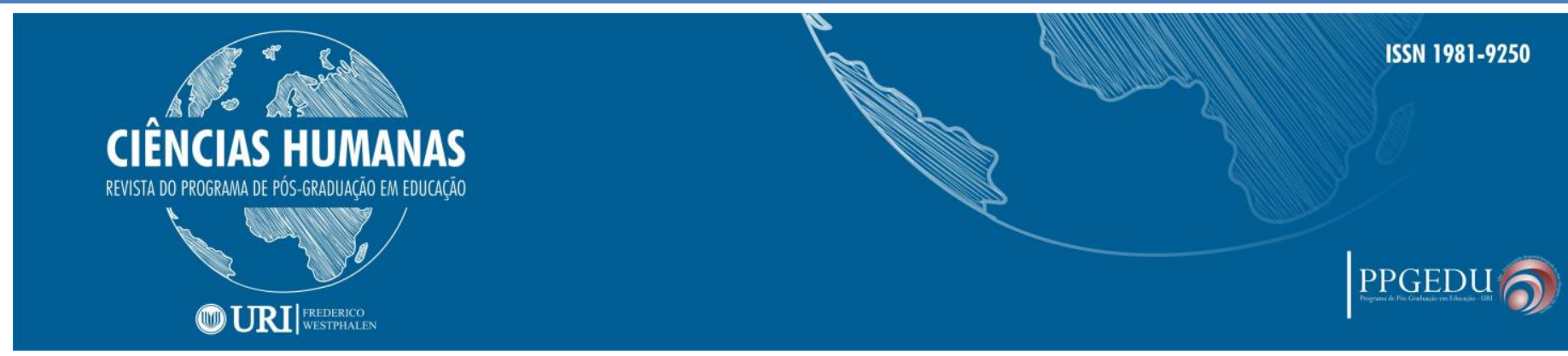

(SANTAELLA, 1994, p.137). Essas reflexões são extremamente pertinentes ao contemporâneo, nesta direção ampliam-se suas fronteiras apontando algumas características:

Falar em estética na contemporaneidade significa, portanto, colocar em cena algumas questões que me parecem fundamentais: 1. a ruptura com a ideia da forma fixa e perene; 2. a incorporação da dimensão do tempo, mas particularmente do tempo real na construção da obra; 3. a incorporação da ideia de relação, isto é, de um fluxo de comunicação e informação que se estabelece entre os agentes que compõem a obra (seja uma relação entre pessoas, como nos trabalhos colaborativos, seja uma relação humano máquina).Todos esses elementos estão presentes com maior ou menor intensidade nas teorias estéticas que procuram, de alguma forma, caminhar lado a lado com as descobertas e os desenvolvimentos tecnocientíficos contemporâneos (SANTAELLA; ARANTES, 2008, p. 29)

Como evidenciado por Santaella e Arantes (2008), é na formação dessa estética que ocorre a intersecção da intersecção do sujeito entre o ator, que por sua vez, passa a engendrar as representações de sujeito/ator mediados pelas tecnologias digitais no ciberespaço. Nesta perspectiva, a vida cotidiana tem sido modulada e construída na complexidade contemporânea, principalmente a partir de uma necessidade ostensiva de aparência e experiência social, constituindo práticas culturais, que apresentam diversidades no modo de olhar, relacionar e mostrar. No palco da vida a relevância se encontra no sucesso estético ${ }^{8}$ da imagem construída, capturada e, sobretudo, exibida no mundo digital. Assim, instituindo o que Goffman (1975) chama de "politeísmo de valores", contextualizado pela "teatralidade cotidiana", ou seja, a "performance" 10 do sujeito/ator contemporâneo. Sua preocupação está fixada em "ser" e "aparecer", sempre

\footnotetext{
${ }^{8}$ Refiro-me ao sucesso estético relacionado ao desejo da captura da imagem perfeita, prática central na vivência e convivência do sujeito/ator. Em tempos de contemporaneidade, a imagem tornou-se linguagem e símbolo, em razão destes fundamentos, o (s) sujeito/ator (s) se reúnem, interagem, produzem, emocionam-se e buscam no outro a aceitação da sua imagem Maffesoli (1995).

${ }^{9}$ [...] o palco apresenta coisas que são simulações. Presume-se que a vida apresenta coisas reais e, às vezes, bem ensaiadas [...]. Na vida real, o papel que um indivíduo desempenha é talhado de acordo com os papéis desempenhados pelos outros presentes e, ainda, esses outros também constituem a plateia (GOFFMAN, 1995, p. 9).

${ }^{10}$ Turner (1987, p. 74) compartilha do ponto de vista que os eventos rituais e os "dramas sociais" configuram na prática um tipo de "metateatro", constituindo um espaço simbólico e de representação metafórica da realidade social, através do jogo de inversão e desempenho de papéis figurativos que sugerem criatividade e propiciam uma experiência singular.
}

\begin{tabular}{c|c|c|c|}
\hline Rev. Ciências Humanas & Frederico Westphalen, RS & Vol. 19 n. 01 & Jan./abr. 2018 \\
\hline
\end{tabular}

\begin{tabular}{l|l|l} 
Recebido em: $18 / 04 / 2018$ & Aceito em: 01/06/2018 & Pg. $95-119$
\end{tabular}




\section{CIÊNCIAS HUMANAS}

REVISTA DO PROGRAMA DE PÓS-GRADUAĞ̈O EM EDUCAĞ̄o

\section{(1) URI|}

em sua melhor "performance", e o corpo é o personagem principal, o suporte maior, o seu protagonista. Sua imagem espetacularizada em rede possui relação com as expressões refletidas em jogos de aparências e poder, tornam-se fachadas no exercício da possível visibilidade como denota (DEBORD, 1997, p.16) “O espetáculo é a afirmação da aparência e a afirmação de toda a vida humana - isto é, social - como simples aparência”.

Neste sentido, se efetiva que "os modos de vida inspiram maneiras de pensar, os modos de pensar criam maneiras de viver" (DELEUZE, 1994, p.17-18). Maneiras de viver que na contemporaneidade são alimentadas pelo imaginário, e este por sua vez, é “alimentado por tecnologias" (2001a. p.69). Tecnologias que em um espaço-tempo romperam com as verdades absolutas. É algo que ultrapassa o indivíduo, que impregna o coletivo ou, ao menos, parte do coletivo. “[...] O imaginário é o estado de espírito de um grupo, de um país, de um Estado-nação, de uma comunidade, etc. O imaginário estabelece vínculo. É cimento social. Logo, se o imaginário liga, une numa mesma atmosfera, não pode ser individual” (MAFFESOLI, 2001a, p.76). Complementa Morin (1998) quando conjuga que, é no imaginário, onde novos conceitos estéticos são liberados, incluindo mitos, sonhos, sentidos íntimos e fantasias. Assim, é fundamental a compreensão da formação estética nos processos formativos do sujeito/ator/narrador/coator, ao passo que, contribui para uma visão mais ampla do conhecimento, busca relevância social, caminha junto e articuladamente compartilhando o pensar, o dizer, o olhar, o perceber na criação deste conhecimento, apoiando-se reciprocamente na qualificação humana intelectual e existencial, pois promove ainda diálogo entre o sujeito e o objeto através da prática desse olhar.

É impossível separar o sujeito/objeto, do viver/conhecer/ ser, ou seja, o sujeito/objeto é produzido e consequentemente conectado a sua relação com o mundo, com os híbridos - sujeitos, lugares, objetos, redes, sensores, servidores, bancos de dados, softwares... - e os modos de mediação. Considerar estas ações e relações na vida social reverbera a inúmeras proporções que a formação estética possa contextualizar no fomento do saber. $\mathrm{O}$ aperfeiçoamento do saber segue passagem no caminho do intelecto etinerado pelas vias da experiência e do sentimento. Neste caminho, a "formação da 


\section{CIÊNCIAS HUMANAS}

REVISTA DO PROGRAMA DE PÓS-GRADUAĞ̈O EM EDUCAĞ̄o

\section{(1) URI|}

sensibilidade é, portanto, a necessidade mais premente da época, não apenas porque ela vem a ser um meio de tornar o conhecimento melhorado eficaz para vida, mas também porque desperta para a própria melhora do conhecimento" (SCHILLER, 1963, p.79). O autor articula que somente a educação levada a efeito por uma concepção estética, onde o sujeito é harmonizado consigo, com a razão, o saber e a sensibilidade, é que se determina a aproximação da estética como instrumento de formação. Movimento que abarca a evolução do sujeito como um todo e aprofunda o conhecimento sistematicamente.

A formação estética é uma educação sentimental e sua existência é automaticamente educativa, unindo conhecimento e emoção, otimizando a relação espectador e vida real pedagogizada, onde toda experiência vivida se transforma em aprendizado. Práticas e compartilhamentos que movimentam os sujeitos/atores a produzir significados a partir da experiência estética, que se faz imperativa na troca de experiências vividas, efetivada a partir da presença do "outro" e na construção de conhecimento. O outro é o "sujeito" principal do evento, o espetáculo constituindo-se somente a partir de sua presença, é a imagem na sua totalidade. Para Bakthin (1992), o ser humano é um ser impossível de se conceber fora de suas relações com o outro. Assim, constitui-se uma nova sensibilidade que privilegia a conexão com o outro, abarcando a participação do sujeito/ator individual num sujeito/ator coletivo, corroborada pela evolução das tecnologias de comunicação.

Nesta perspectiva, Maffesoli (1995) contribui referindo-se a imagem como central na vivência dos sujeitos, corroborando para a formação enquanto incentiva a busca frenética pelo prazer, pela estética, pelo sentido, pelo belo. $\mathrm{O}$ autor aposta em um paradigma estético que compreende as emoções compartilhadas e fomentadas nas mídias sociais como vetor social, instigando a necessidade de pertencer a esta conexão, de estar junto, de se legitimar perante suas faces e aceitação do outro. Condutas, comportamentos e relações que são construídas e fortalecidas culturalmente na interação, na confiança e nos laços afetivos, conforme (BERTOLINI; BRAVO, 2004). Assim, o sistema de interação mediada por computador proporcionado pelas redes sociais influencia sintonizando o sujeito através da interação com o global, o local, o 


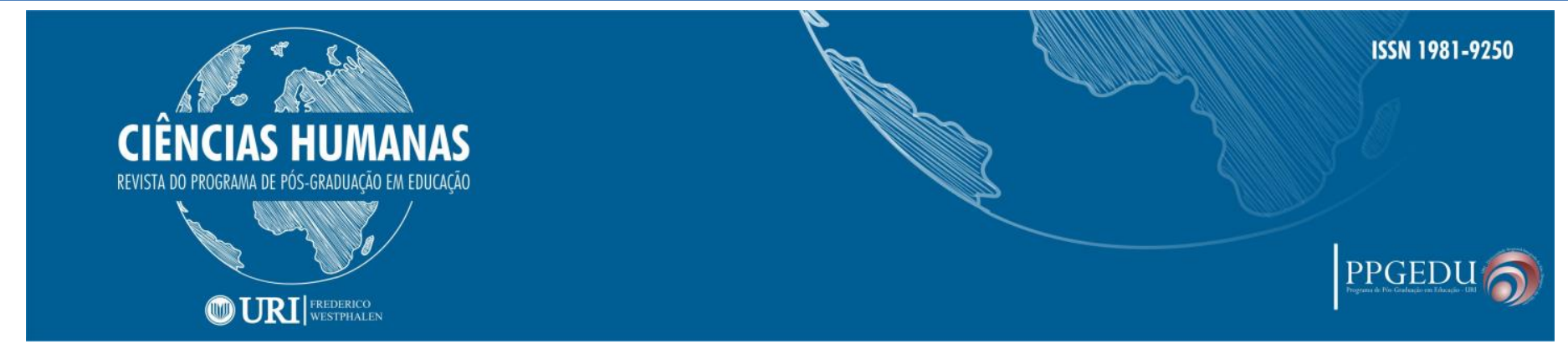

cotidiano, com o novo e o outro. O sujeito é aquele que compartilha sua formação estética em suas produções fotográficas e narrativas escritas aludidas em histórias singulares, contadas por intermédio de suas composições, luzes, linguagens e ou ângulos inusitados. Contribuindo ainda, para a construção e escala de um sujeito/ator/narrador/coator que ora se conecta e se inter-relaciona como usuário/consumidor.

\section{ANÁLISES DA FORMAÇÃO ESTÉTICA}

Na prática pedagógica desenvolvida com os acadêmicos do curso de Fotografia, observamos e organizamos os dados empíricos a fim de evidenciar os sinais gerados pelos sujeitos participantes, por intermédio de compartilhamento nesta mídia social em relação à formação estética. Para tanto, as análises referentes a prática pedagógica foram realizadas a partir de Três imagens submetidas a investigação semiótica, sendo que, cada uma delas contextualiza inicialmente a narrativa escrita sobre a experiência da produção da imagem fotográfica do acadêmico na realização de sua "obra". Logo abaixo, teremos a fotografia construída pelo mesmo e na sua lateral as interações que corroboraram para o fomento da formação estética dos sujeitos que não são aquele que criou a imagem e sim "o outro" e por fim, os comentários da pesquisadora. Neste caminho, os acadêmicos percorrem na pedagogização ora como sujeitos, atores, narradores e também ora como coatores no decorrer do processo.

\section{NARRATIVAS DO ALUNO}




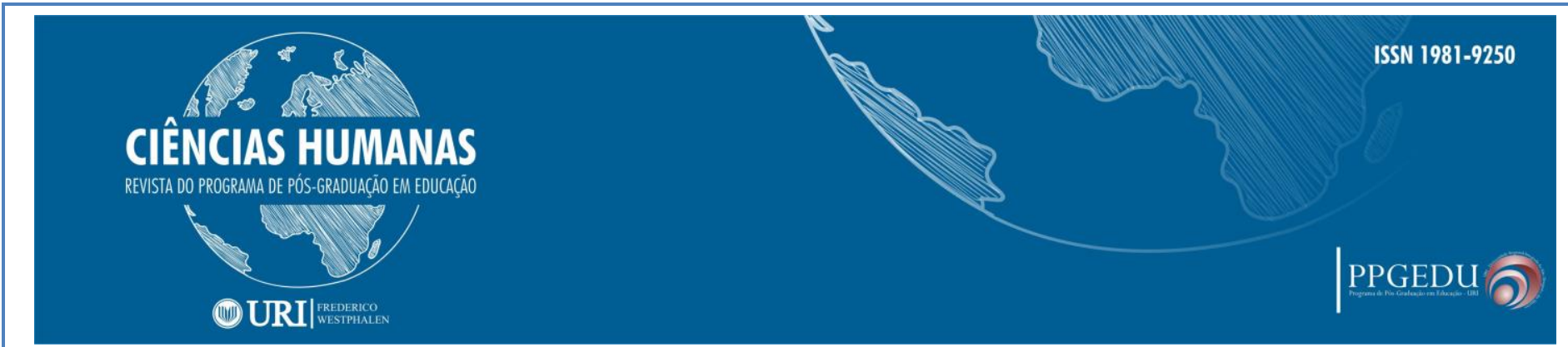

A semana acadêmica foi preenchida de oficinas/palestras de diferentes áreas com variadas propostas. O aluno teve a oportunidade de ampliar seu conhecimento já existente e absorver novos, potencializando sua percepção. Fiz inscrição para oficinas/palestras em todos os dias, aproveitando ao máximo esse momento. Ao fim da semana, minhas expectativas foram atingidas. Construí essa imagem pensando, primeiramente, em movimento. No andar dos alunos em busca de experiências, no transito entre um lugar e outro. Como se contasse uma história, um momento, uma sensação. A velocidade baixa foi usada para não revelar rostos, fazendo com que o indivíduo que irá olhar a foto não identifique ninguém, apenas pessoas e corpos, para que consiga imaginar qualquer um ali. A escolha do preto e branco foi para que não houvesse distrações com cores ao ver a imagem, o foco total nas linhas e no movimento. O enquadramento nos remete a algo sem fim, uma escada que sobe e não enxergamos o final, assim como o conhecimento que adquirimos. Uma escada na qual subiremos sempre, em uma constante busca de aprendizado.

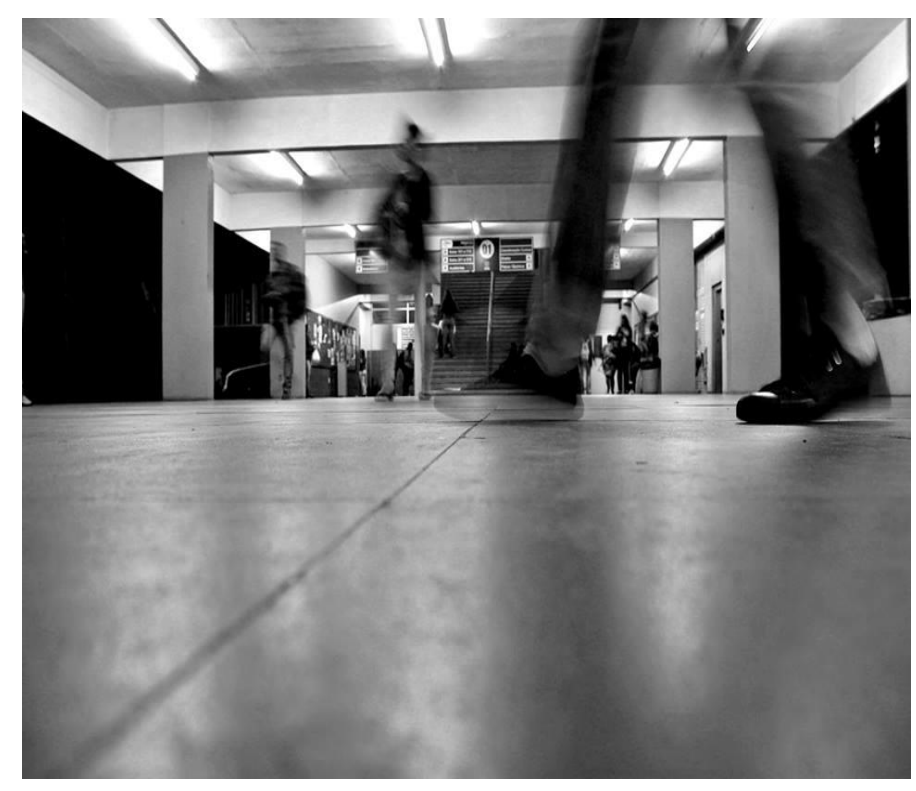

FIGURA 01 - O HOJE E O AGORA

Fonte: Jonas, pesquisa de campo

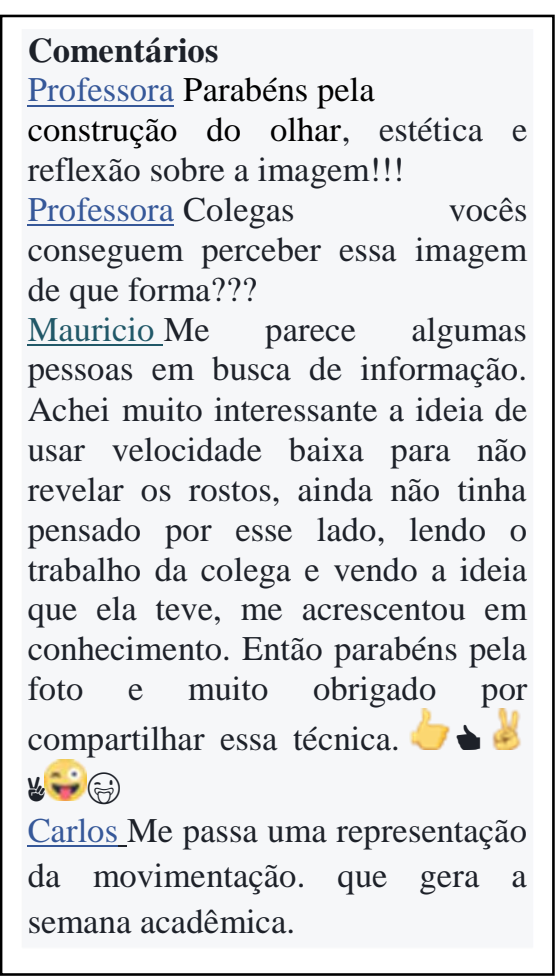

Primeiramente, identifica-se que a fotografia acima foi capturada através de percepção, observação, crítica, inspiração, análise do espaço físico e planejamento, a partir desses estímulos e intencionalidade, o acadêmico passou a explorar mais 


\section{CIÊNCIAS HUMANAS}

REVISTA DO PROGRAMA DE PÓS-GRADUAĞ̈O EM EDUCAĞ̄o

\section{(1) URI|}

detalhadamente a formação estética na sua mais nova "obra" intitulada pelo mesmo de "O Hoje e o Agora".

Uma vez que, seu propósito é compor e produzir uma imagem impactante esteticamente, ou seja, sensível e ao mesmo tempo técnica, estes são atributos que todo o acadêmico da área da fotografia almeja na captura da imagem como prática fotográfica. Como nos afirma Maffesoli (2000) "o termo estético de maneira etimológica, é como a faculdade comum de sentir, de experimentar" (p. 105). E nesta caminhada investigativa, este é um processo comprometido com a evolução da inspiração, do desenvolvimento criativo, sensível e transformador, ao passo que, viabiliza a construção da formação estética enquanto aprendizado e conhecimento.

A imagem produzida pelo acadêmico carrega muitas interpretações a partir de sua essência, denota movimento, experiências, trânsito intenso, uma composição de luzes, sensações e sentimentos, conforme observamos em sua narrativa. E estas interpretações são desenvolvidas segundo Santaella (2002), por meio do exercício de um olhar na pretensão da captura de uma estética contemplativa, uma estética que descrimina e generaliza os processos de interpretação. Processos que na semiótica Pirceana (1978) são tradados da seguinte forma: à primeiridade, que é o contato sentimental com a imagem, corresponde a fase da significação e seguindo os passos do acadêmico este é o momento que ele se deteve aos aspectos qualitativos vinculados às cores, às formas, às linhas, às texturas, ao movimento, às dimensões ou ao jogo de elementos. Estando ainda, em um processo sensorial no qual, a sensibilidade percorre o campo da qualidade e acaba ampliando essa sensoriedade. O segundo passo chama-se secundidade, é a interpretação racional, diz respeito à referência, é a fase da objetivação. Nessa faceta, a análise semiótica nos permite compreender aquilo que as mensagens indicam, aquilo a que se referem ou a que se aplicam. Devem-se desenvolver considerações situacionais sobre o universo no qual o signo se manifesta e do qual é parte. O terceiro passo é o da terceiridade, é o momento do raciocínio, à postura crítica generalizante, a fase da interpretação, leva-nos ao exame dos efeitos que os elementos apreendidos até então podem provocar no intérprete, entram aqui os conhecimentos daquele que olha sobre cada elemento da imagem que vê, conhecimento este que permitirá a articulação das 


\section{CIÊNCIAS HUMANAS}

REVISTA DO PROGRAMA DE PÓS-GRADUAĞ̈O EM EDUCAĞ̄o

\section{(10)URI|}

qualidades atualizadas existentes no processo, que caracteriza a ação do signo produzindo outros signos.

Nessa perspectiva, vê-se um signo a partir do momento em que se deduz uma significação dependendo da cultura que se está inserido, logo, um objeto pode significar outra coisa em outra cultura, depende da relação do objeto com aquele que o vê. O ícone corresponde à classe dos signos cujo significante mantém uma relação de analogia com aquilo que ele representa, ou seja, com o seu referente. $\mathrm{O}$ índice mantém uma relação causal de contiguidade física com aquilo que eles representam, como o caso dos signos naturais. E o símbolo mantém com o seu referente uma relação de convenção com os símbolos clássicos, sempre acompanhados de sua linguagem imagética. E a composição estética acompanhada de toda essa experiência reúne conhecimento, emoção e sentimento, transformando toda experiência vivida em aprendizado.

A imagem compartilhada com o grupo provocou interação entre alguns colegas motivados pela formação estética, pela modulação nas suas narrativas e também pela técnica fotográfica utilizada na sua composição. Aspectos que causaram surpresa e também admiração, ao passo que, sua percepção na construção da imagem e sensibilidade se tornou clarificador para aqueles que por hora assistem o espetáculo como coatores. E o grupo, conectados a esta rede estão compartilhando diversas formas de perceber, olhar, interpretar e sentir seus mundos por intermédio da produção e exibição de suas imagens.

Esses novos papéis estão ocorrendo em rede, uma ampla teia, que proporciona diferentes saberes, entre a teoria e a prática educativa, conexões que contribuem para reflexões na construção do conhecimento referente à composição da imagem e a formação estética. Desse modo, podemos pensar na formação estética como uma experiência nunca fixa ou estática, pois o acadêmico aborda acerca do visual e ou significado que a imagem contempla, ao passo que interpreta em sua escrita os reflexos que os tons transmitem sejam por formas ou luz. Cita a relevância dos tons escuros partir de sua transmissão por uma estética contemporânea e inclusive criativa, não só percebe como sente essa estética que emociona através da tranquilidade e sensibilidade, 


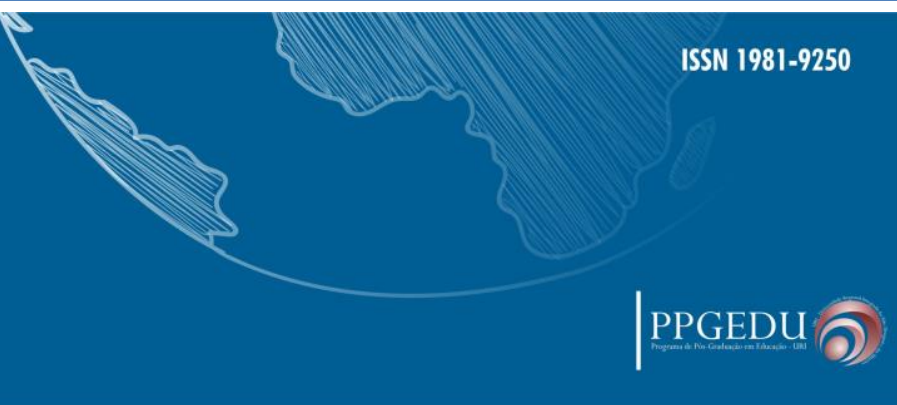

nunca esquecendo da criatividade - característica fundamental para o artista e sua profissão.

\section{NARRATIVAS DA ALUNA}

Escolhi fazer essa foto porque foi um dos melhores momentos que tive na semana acadêmica. Ter aprendido e poder ensinar sobre a Fotografia Lambe-Lambe me foi uma grande alegria. Para resumir a diversão da noite, criei esta foto com alguns dos alunos que participaram da oficina, com a intenção de mostrar a animação e surpresa deles no seu encontro com a histórica câmera Lambe-Lambe. Me foi muito especial ver o quanto os alunos se interessaram e ficaram contentes ao fotografar com essa câmera. Pedi para que posicionassem as mãos assim para passar a ideia de novidade, de surpresa ao se depararem com a história de uma câmera que ajudou a popularizar o retrato nas ruas, e a levar a fotografia para pessoas d A técnica da fotografia LambeDecidi fazer um tratamento de imagem sutilmente colorid $\begin{aligned} & \text { Lambe é a mesma das demais } \\ & \text { câmeras analógicas. Um papel }\end{aligned}$ acompanhou o sentimento do momento.

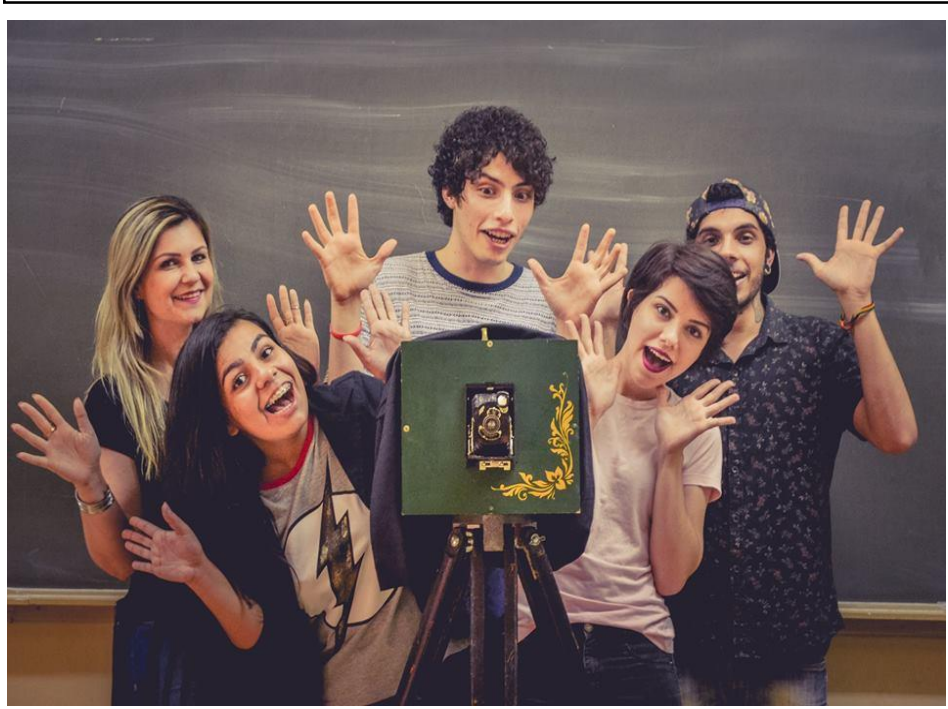

FIGURA 02 - A FOTOGRAFIA LAMBE-LAMBE Fonte: Francine, pesquisa de campo sensibilizado é colocado em contato com a luz dentro da Câmera (usamos filme de Raio X), e após o disparo, uma imagem é gravada e recebe um banho de revelador e fixador, tudo dentro da caixa acoplada a câmera, caixa essa que é um mini-laboratório de revelação. Depois deste processo, o resultado até aqui é de uma imagem negativa. Para positivá-la, fizemos a cópia por contato através do processo de cianotipia (cópia azul). A grande diferença do processo analógico para as demais câmeras, está no fato de que a imagem do filme é análoga a sua reprodução.

Professora Quem dos colegas conhece a técnica?

Jessica Conheço a técnica. Acabei não fazendo essa oficina, mas na cadeira de PB fizemos alguns cianóticos e ainda tenho alguns trabalhos guardados $=$

Nessa oficina foi performatizada ${ }^{11}$ a técnica

fotográfica analógica através da câmera chamada Lambe-Lambe, conforme observamos

11 [...] o palco apresenta coisas que são simulações. Presume-se que a vida apresenta coisas reais e, às vezes, bem ensaiadas [...]. Na vida real, o papel que um indivíduo desempenha é

\begin{tabular}{c|c|c|c|}
\hline Rev. Ciências Humanas & Frederico Westphalen, RS & Vol. 19 n. 01 & Jan./abr. 2018 \\
\hline
\end{tabular}

Recebido em: 18/04/2018 $\quad$ Aceito em: 01/06/2018

Pg. $95-119$




\section{CIÊNCIAS HUMANAS}

REVISTA DO PROGRAMA DE PÓS-GRADUAĞ̈O EM EDUCAĞ̄o

\section{(1) URI|}

na narrativa da aluna. Assim, nestes termos, ficou conhecida a caixa preta adaptada para produzir imagens das classes mais simples da população. Até a final descoberta da fotografia muitos estudiosos se aventuraram para descobrir essa tecnologia, uma das mais importantes da história no seu contexto.

$\mathrm{Na}$ atualidade vivemos uma era digital e sua evolução técnica é atribuída transversalmente ao desenvolvimento desta tecnologia, que teve perene participação dos meios de informação e a comunicação. As técnicas são oferecidas como um sistema e realizadas combinadamente através do trabalho e dos lugares de seu uso, ou seja, a cada evolução técnica, uma nova etapa histórica se torna possível.

O desenvolvimento da história ocorre na articulação com o desenvolvimento das técnicas, cada sistema técnico representa uma época e o resultado das ações assegura a emergência de um mercado. Devido a evolução técnica, a fotografia se faz presente na atualidade em todos os meios de socialização, muitos são os sentidos, sentimentos, representações e saberes construídos por intermédio de suas conexões. Sendo assim, a união entre produzir imagem e construir uma narrativa por intermédio da experiência individual e coletiva, passou a incitar a acadêmica a uma forte modulação em sua narrativa como podemos observar na interação ao lado. Fomentada a partilhar suas experiências com o grupo, enquanto trocava conhecimento narrando a história da fotografia, ou ainda compartilhando sua formação estética por intermédio de seu olhar representado pelas composições, linguagens e ou ângulos inusitados. Visto que, produzir imagens contribui ao incentivo do consumo de si ao passo que, proporciona constituir modos de inclusão, aproximação e estar-junto. Acentuando-se em grande escala o crescimento do que é impessoal, uma estética tribal ${ }^{12}$, a perda de si no outro, a partir do gosto compartilhado, enfim, a criação da imagem e sua consumação. E a estética neste contexto, também contribui com uma função evolutiva, "estando seu significado pleno apenas num futuro distante sempre concretamente adiado. Um futuro idealmente pensável, mas materialmente inatingível" (SANTAELLA, 1994, p.137). Um

talhado de acordo com os papéis desempenhados pelos outros presentes e, ainda, esses outros também constituem a plateia (GOFFMAN, 1995, p. 9).

12 Maffesoli (2001) chama de tribal a cultura do sentimento, expressa o desejo de um cotidiano mais emocionante, mais brilhante, mais místico, no qual, o sujeito escolhe recriar o estético, o que lhe encanta ou o que lhe retira a dor, ou seja, uma "iluminação estética do cotidiano".

\begin{tabular}{l|l|l|l}
\hline Rev. Ciências Humanas & Frederico Westphalen, RS & Vol. 19 n. 01 & Jan./abr. 2018 \\
\hline
\end{tabular}

\begin{tabular}{l|l|l} 
Recebido em: 18/04/2018 & Aceito em: 01/06/2018 & Pg. 95 - 119
\end{tabular}




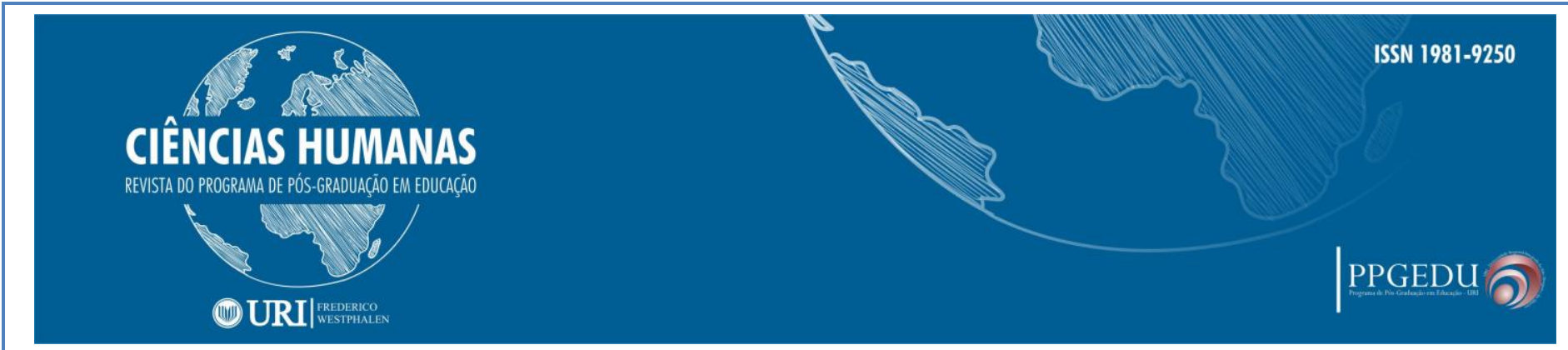

futuro que para os acadêmicos é o agora, materialmente inatingível, mas perceptível em sua formação estética, estes são os sinais que percebemos na imagem acima. Os participantes da oficina não se conheciam e através de interação para a técnica e a captura fotográfica foram sensibilizados e tocados, enquanto a acadêmica idealiza através da performatividade do grupo uma imagem que a inspire e "toque". Passaram então, a construir sentido, saberes, sentimento pelo coletivo ao passo que criaram laços, enquanto trocavam experiências e atuavam ora como atores e coatores.

O compartilhamento deste trabalho trouxe algumas discussões que foram gerando um maior vínculo e fluxo entre alguns acadêmicos e uma maior participação da autora como podemos perceber de maneira crítica e transformadora.

\section{NARRATIVAS DO ALUNO}

Participei da oficina de Roberto Majola, sobre fotografia de ambientes. Ele trouxe um pouco das peculiaridades da fotografia de ambiente e o que ela difere da fotografia de arquitetura. Para representar um pouco da minha visão do momento, fiz uma foto mais voltada à arquitetura fugindo um pouco da proposta dada pelo palestrante. Nela usei tons mais claros como o azul fraco, para significar a tranquilidade e o céu iluminado (fazendo total ligação com o local religioso, a Capela). Podemos representar a estrutura de aço como a imensidão do espaço ao nosso redor, e o órgão de tubos como o indivíduo buscando a clareza de pensamentos. Nesse tipo de imagem, acredito que a foto seja apenas um registro do trabalho do designer, que é o verdadeiro autor da composição através de suas linhas. 


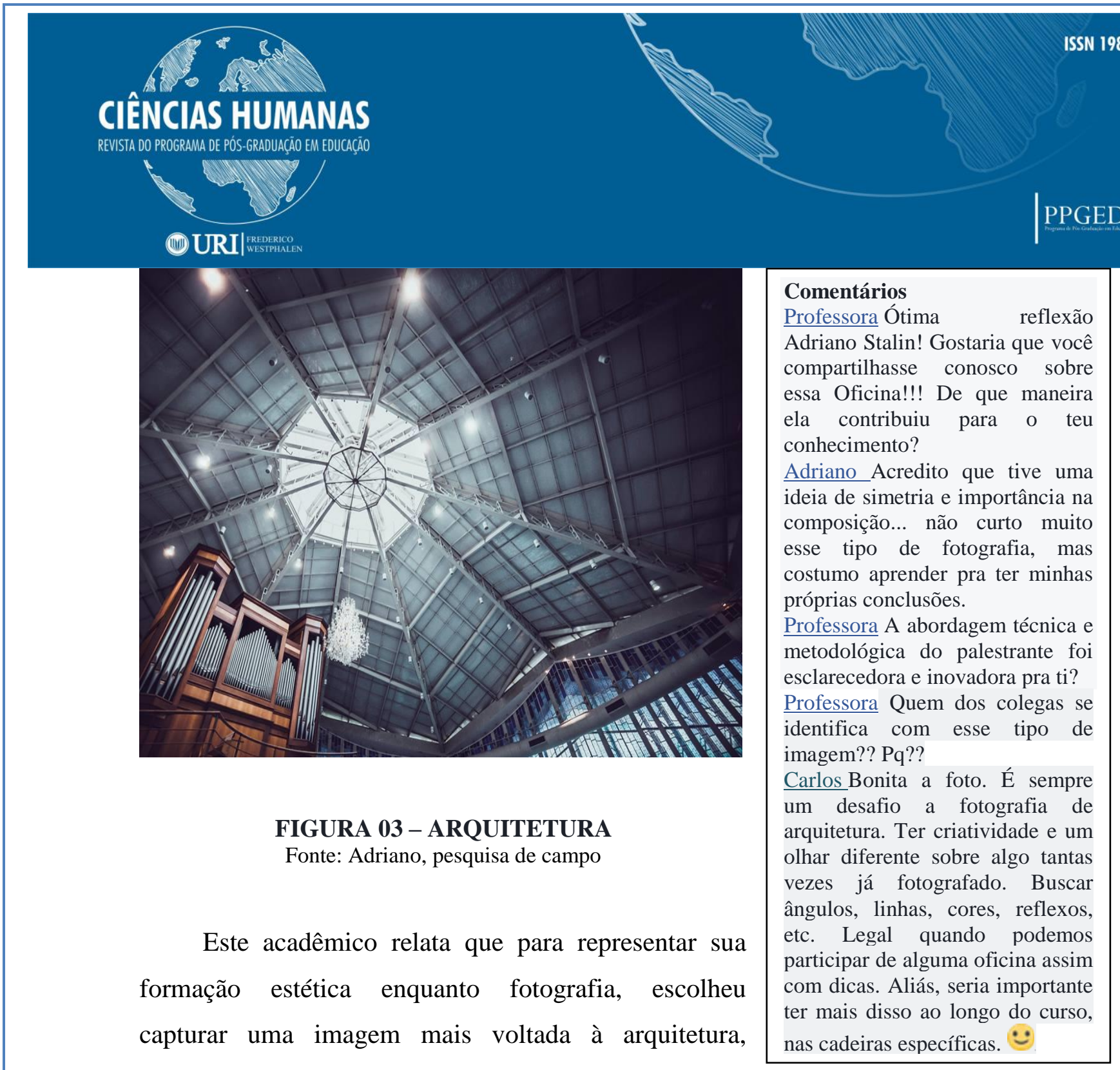
fugindo um pouco da proposta dada pelo palestrante não referência qual seria a proposta. Percebemos através de sua narrativa escrita e imagética que a obra construída e compartilhada no Facebook possui diversas interferências no entorno de sua produção estética, ao passo que, o acadêmico ressignifica conceitos culturais enquanto contempla as estruturas, os objetos, as linhas e as cores. Nesta perspectiva, consideramos que o mesmo encontra-se no primeiro olhar, aquele que contempla e corresponde à face da significação, ou seja, o momento em que ele se deteve nos aspectos qualitativos referentes a imagem que está vendo. Nessa trilha, seu o imaginário ${ }^{13}$ passou a engendrar novos símbolos, linguagens, representações, emoções e sentimentos, o olhar agora está observando, diz respeito à referência, é a fase

\footnotetext{
${ }^{13}$ Complementa Morin (1998) quando conjuga que, é no imaginário, onde novos conceitos estéticos são liberados, incluindo mitos, sonhos, sentidos íntimos e fantasias.
}

\begin{tabular}{c|c|c|c}
\hline Rev. Ciências Humanas & \multicolumn{2}{|c|}{ Frederico Westphalen, RS } & \multicolumn{2}{c}{ Vol. 19 n. 01 } & Jan./abr. 2018 \\
\hline Recebido em: 18/04/2018 & Aceito em: 01/06/2018 & Pg. 95 - 119 \\
\hline
\end{tabular}




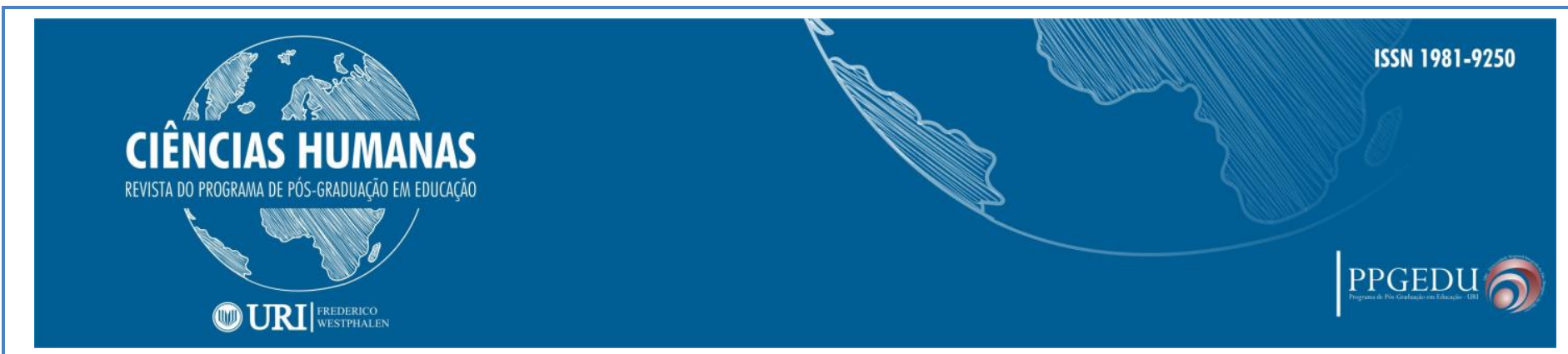

da objetivação. Nessa faceta, a análise semiótica nos permite compreender aquilo que as mensagens indicam, aquilo a que se referem ou a que se aplicam. Em seguida, entra em ação o olhar generalizante, aquele que provoca efeitos sobre os elementos apreendidos naquele que vê e lê a imagem, além de agregar e permitir conhecimento enquanto articula qualidades atualizadas existentes no processo, que caracteriza a ação do signo produzindo outros signos. Estes três passos semióticos referentes ao olhar alimentam a formação estética daquele que está olhando e se constituindo neste processo.

Na narrativa escrita deste acadêmico fica claro a sua preocupação em formar uma imagem que toque, que carregue consigo sentimento. Estes desejos englobam a preocupação por uma estética do sensível, uma estética que toque e comova aquele que olha, vê, percebe e observa. Nesse processo, configura-se o estado poético, aquele que se transforma em estado de emoção e de afetividade. O estado poético é a produção de si mesmo, o autofazimento que provoca um protagonismo transformador, onde se respeita e enriquece a diversidade. E a poési compartilha da mesma raiz grega com a palavra "poesia" que significa "criação". A criação alimentada pela formação estética conduziu o acadêmico a escolher tons frios como o azul para a sua composição fotográfica, que pode significar tranquilidade, serenidade e harmonia, juntamente com o céu iluminado; conexão que o mesmo reitera à Capela como um local religioso. $\mathrm{O}$ seu protagonismo crítico, inspirador e transformador se deu a partir da observação e posteriormente de um planejamento simétrico colocando em prática o olhar, o perceber, o ver, o sentir, o emocionar e o criar. Movimentos que abarcam a evolução deste sujeito enquanto compõe sua obra com toda a amplitude de sua formação estética.

\section{CONSIDERAÇÕES FINAIS}

Percorrer os caminhos investigativos da semiótica contemplando analisar como se dá a formação estética a partir da prática pedagógica sugerida - unir a produção de imagens e a narrativa escrita sobre a experiência - com os acadêmicos de fotografia, possibilitou evidenciar o crescimento tanto em suas narrativas, como a extensão do perceber, sentir, olhar e ser tocado a cada nova imagem (fotografias) produzida. 


\section{CIÊNCIAS HUMANAS}

REVISTA DO PROGRAMA DE PÓS-GRADUAĞ̈O EM EDUCAĞ̄o

\section{(10)URI|}

Modulações narrativas que se ligam a formação estética a cada nova construção de sentido construídas em suas histórias singulares também enquanto imagem, ora representadas por olhares, composições, luzes, linguagens e ou ângulos inusitados.

Os processos na construção de sentido enquanto formação estética na produção de suas imagens decorreram a partir da observação pela descrição livre da aparência forma -, portanto, suas histórias singulares enquanto imagem foram representadas nesta pesquisa por composições fotográficas articuladas a contextos variados, apoiadas inicialmente no que é observável por parte do olhar do fotógrafo. De acordo com Maffesoli (1996), “a forma é apenas uma tipificação elaborada a partir de dados observáveis, feitos à base de descrições, sem que se trate de suspeitar, criticar o que é observado ou descrito" (p. 143). No entanto, a construção do conhecimento e da imagem a partir da formação estética possui sua origem na reflexão e na crítica, sendo moldada a partir da percepção, das interferências sociais, das reflexões, dos significados ou representações que cada acadêmico vê, imagina, articula e produz. Neste interim, as narrativas escritas e imagéticas produzidas que foram fomentadas pelos sentidos e sentimentos, aos poucos, contribuíram para o desenvolvimento dos mesmos de modo crítico, inspirador e transformador.

O modo critico se dá como uma espécie de desregulamentação, à medida que o sujeito se senti ocupado pela necessidade de construir novos paradigmas de compreensão e avaliação sob o que está produzindo. Já o modo inspirador é um estado de espírito, caminha na dimensão do imaginário, potencializando o processo criativo, a novidade, o extrapolar, envolvendo e ultrapassando a obra. Enquanto o modo transformador, revela as percepções, os sentidos, as representações, as emoções, as interfaces como potências sensoriais e afetivas nos cruzamentos entre narrativa escrita e produção de imagens. Sendo assim, observamos que a formação estética percorre múltiplos caminhos a partir da extensão de um olhar, seguido pela construção de sentidos, atribuindo significados aquilo que representa e nesse desdobramento um novo sentir opera na evolução criativa.

Assim identifica-se que, a produção imagética e narrativa escrita pelos acadêmicos de fotografia promoveu a possibilidade de construção da formação estética 


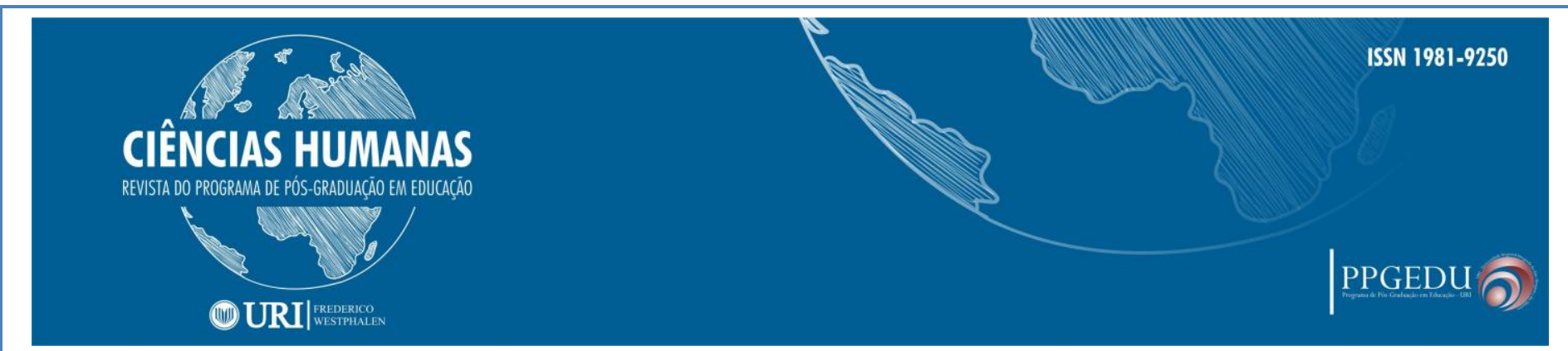

de cada "eu" singular e coletivo, enquanto sujeito/ator/narrador/coator através do esforço dispendido na produção de sua obra de "arte", à medida que compartilhou suas expectativas, técnicas, frustações e experiências vividas. A partir destas, na construção do sentir e ser tocado pela formação estética, passaram a ressignificar suas representações, atribuindo a elas conhecimento, criação, inspiração e emoção em um protagonismo transformador.

Neste sentido, esta prática educativa, movimenta-se como método de aprendizagem, contribuindo ao fomento de múltiplas experiências, trocas, permutas e aspirações tão inovadoras como artísticas. Enfim, a formação estética através da construção de imagem e de narrativas escritas, expande percepções visuais, sociais, e comportamentais, isto é, efeitos tanto epistemológicos como empíricos que corroboram nas diversas formas de pensar, agir, ser, sentir, tocar e ser tocado.

A formação estética é uma educação sentimental e sua existência é automaticamente educativa, unindo conhecimento e emoção, otimizando a relação espectador e vida real pedagogizada, onde toda experiência vivida se transforma em aprendizado. Práticas e compartilhamentos que movimentam os sujeitos/atores a produzir significados a partir da experiência estética, que se faz imperativa na troca de experiências vividas, efetivada a partir da presença do "outro" e na construção de conhecimento.

\section{REFERÊNCIAS}

BAKTHIN, Mikhail. Marxismo e filosofia da linguagem. 6. ed. São Paulo: Hucitec, 1992.

BERTOLINI, Sonia.; BRAVO, Giangiacomo. Social capital, a multidimensional concept. 2004. Disponível em:

<http://web.archive.org/web/20030318075349/http://www.ex.ac.uk/

shipss/politics/research/ socialcapital/other/bertolini.pdf>. Acesso em: 14março. 2018.

BENJAMIN, Walter. A obra de arte na era de sua reprodutibilidade técnica.

In: Obras escolhidas, I. São Paulo: Brasiliense, 1985.

BENJAMIN, Walter. A obra de arte na era de sua reprodutibilidade técnica. 


\section{(1) URI|}

In: Obras escolhidas, I. São Paulo: Brasiliense, 1994.

DEBORD, Guy. A sociedade do espetáculo. Contra Ponto. Rio de Janeiro, 1997, p.16.

DELEUZE, Gilles. Nietzsche. Lisboa: Edições 70, 1994, p. 17-18.

GOFFMAN, Erwin. A Representação do Eu na Vida Cotidiana. Petrópolis: Ed. Vozes, 1975.

GOFFMAN, Erwin. A Representação do eu na vida cotidiana. 3. ed. Petrópolis: Vozes, 1995.

MAFFESOLI, Michel. A contemplação do mundo. Tradução de Francisco Franke Settineri. Porto Alegre: Artes e Ofícios, 1995.

MAFFESOLI, Michel. No fundo das aparências. Petrópolis, Rio de Janeiro: Vozes, 1996.

MAFFESOLI, Michel. O tempo retorna: formas elementares da pós-modernidade. Rio de Janeiro: Forense Universitária, 1998.

MAFFESOLI, Michel. O tempo das tribos: o declínio do individualismo nas sociedades de massa (3a ed.). Rio de janeiro: forense, 2000, p. 105.

MAFFESOLI, Michel. O eterno instante. O retorno do trágico nas sociedades pósmodernas. Lisboa: Instituto Piaget, 2001.

MAFFESOLI, Michel. O imaginário é uma realidade. Revista Famecos. Mídia cultura e tecnologia. $\mathrm{N}^{\text {o } 15}$, ago. 2001a. Porto Alegre: EDIPUCRS, p.74-81.

MORIN, Edgar. O método. Porto Alegre: Sulina, 1998.

SANTAELlA, Maria Lucia. Estética de Platão a Peirce. S.P: Experimento, 1994.

SANTAELlA, Maria Lucia. Estética de Platão a Peirce. S.P: Experimento, 1998, p. 117.

SANTAELLA, Maria Lucia. Da cultura das mídias à cibercultura: o advento do póshumano. Revista FAMECOS. Porto Alegre, nº 22, p. 23-32, dezembro 2002.

SANTAELLA, Maria Lucia. Semiótica aplicada. São Paulo: Thomson, 2002.

SANTAELLA, Maria Lucia. ARANTES, Priscila (orgs.). Estéticas Tecnológicas, novos modos de sentir. São Paulo: EDUC, 2008. 


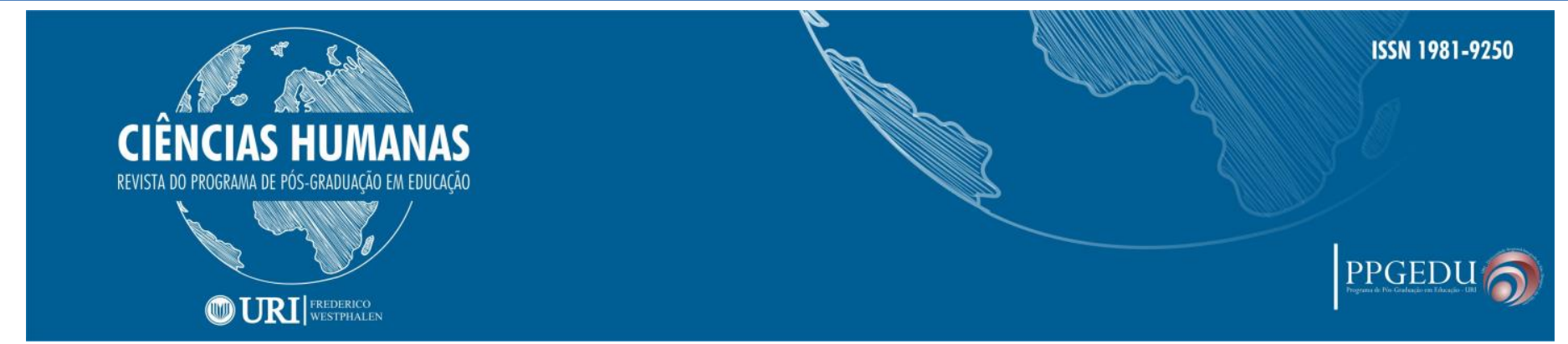

SCHILLER, Friedrich. Cartas sobre a Educação Estética da Humanidade. Tradução de Roberto Schwarz. São Paulo: Herder, 1963, p.79.

TURNER, Victor. The Anthropology of performance. New York: PAJ Publications, 1987. 